\title{
The Development of Synectic Models in Learning Writing in Short Story in the Class XI of Medan UISU High School
}

\author{
Rini Sartika Nasution ${ }^{1}$, Mutsyuhito Solin ${ }^{2}$, Malan Lubis ${ }^{2}$ \\ ${ }^{1}$ Master Student in, Universitas Negeri Medan, Medan, Indonesia \\ ${ }^{2}$ Lecturer in Universitas Negeri Medan, Medan, Indonesia \\ rinidailystory@gmail.com
}

\begin{abstract}
This research and development based on the phenomenon that there are still many students who have difficulty in writing short stories and the importance of educators innovating in the use of learning models in an effort to improve the achievement of learning objectives. This study aims to (1) Describe the process of developing synectic models in short story writing students in class XI students of UISU Senior High School Medan (2) Describe the feasibility of developing synectic models in learning to write short stories in class XI students of SMA UISU Medan (3) in learning to write short stories at XI grade students of UISU Medan High School. This type of research is development research based on the development model 4-D of Thiagarajan. The trial subjects consisted of material experts, design experts, Indonesian language educators, and XI grade students of UISU Medan High School. Validation results show an average percentage of $92.12 \%$ for learning material and an average percentage of $95.13 \%$ for learning design with excellent advice. The effectiveness of the product is obtained from a learning motivation questionnaire in a limited trial and is supported. Limited trials show an average percentage of $93.45 \%$ with very good criteria and approval trials of $95.12 \%$ with very good criteria. The data is also supported by the observations of students also increasing the pretest value from 64.83 to the posttest with an average value of 80.47 . This proves that the synectic model developed for learning to write short stories is feasible to use and can improve students' ability to write short stories.
\end{abstract}

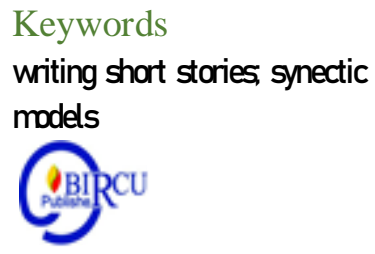

\section{Introduction}

Write short story is one of the competencies that must be mastered learners class XI in Curriculum 2013. Hidayati (2009:91) suggests that, the notion write story short it is itself an expression of experience, ideas or ideas through the form of language daily that are prepared as best as possible, so that to form a story in the form of fiction that can be completed to read approximately 10 to 30 minutes.

Writing text stories are not able to do so alone without knowing the process of creative writing. The obstacle faced by students is the inability to utilize all the potential to obtain and develop ideas for writing. Teacher need to innovate to overcome obstacles in the teaching of writing one of them by developing learning models. The model of learning which was developed with the well will provide many benefit, among others increase interest in learning and help learner is able to solve various problem in learning, and help get the experience of learning that is more meaningful. 
Selection of the model right can help learners achieve the purpose of learning or do internalize the content or materials of learning. The model of learning which was developed with the well provide many benefits, among others increase interest in learning and help student were able to solve a variety of problems in learning, and help get the experience of learning that is more meaningful.

One of the models of learning that is designed for teaching that is designed for teaching writing that introduce the students undergo a process of creative is a synectic model. Gordon (in Joyce and Weil, 1992: 220) revealed that the synectic learning model aims to develop student's creativity through metaporic activities. More advanced again, Gordon (in Joyce and Weil, 1992: 236) disclose various metaporic are expected students can connect an aspect, comparing between object/ideas ate the same and / or different by using an object replacement.

The synectic model in writing learning has been proven by several previous research such as Sri Ramadhani in the journal Research and Method in Education entitled" The Effect of Synectics Learning Model and Vocabulary Mastering to Student Writing Poetry Skills in Grade $\mathrm{V}$ vol.7 number 5 page $80-88$ shows that students ability to write poetry is better when using synectic models. Listini and Saraswati's research in the journal Bindo entitled "Improving the Short Story Writing Ability through a Synectic Learning Model for Class VII Students of Sandika Sukajadi Middle School" vol. 1 no. 1 page 24-27 proves that the synectic model can improve students' short story writing skills.

The results of observations and interviews in the field with educators Bahasa in SMA UISU Medan, teachers are always trying to give students motivation in writing short stories but teachers experiencing barriers to doing innovation on models of learning as a result do not have much time to spare. Participants are students still difficult to develop ideas and shape the idea that to in a short story even though educators using a model of learning synectic. It is demonstrated that the model synectic still have to be developed so that the students know how to follow the process of the creative that should be passed in writing.

Students find difficulty determining the idea of a story that is appropriate and develop it into a story that is intact and attractive. Students are not able to explore a variety of things that exist in the vicinity and make things such as inspiration to write. How that can be done in order to accommodate all the shortcomings it is the development model of learning to write short stories by utilizing sources of power that exist .

Santyasa (2007) revealed the use of models would be more useful, if teachers innovate in designing learning models according to the conditions in the field and the characteristics of students. Innovation in here interpreted as an attempt to obtain the acceleration of the process and the beauty of the result of learning based on freedom and diversity.

Based on the description in the above, the researcher was interested and need to do some research the development of the model of learning synectic in learning to write short stories. The purpose of this study is (1) to describe the process of developing synectic models in learning to write short stories in class XI students of SMAUISU Medan (2) describing the feasibility of developing synectic models in learning to write short stories in class XI students of SMA UISU Medan (3) knowing the effectiveness of the development results synectic model in learning to write short stories in class XI students of SMA UISU Medan 


\section{Research Method}

This research is a type of development research. The development of learning models will be carried out using the 4-D development model from Thiagarajan (1974). The 4-D model consists of four stages: defining, designing, developing, and disseminating.

Phase definition (define) is the stage for establishing and defining the terms of development. This stage is often called a needs analysis. In general, in this definition the development needs analysis is carried out, the requirements for product development in accordance with the appropriate research and development model are used to develop the product.

The design phase ( design ) consists of four activities namely compiling the test criteria, as the first step to find out the students' initial abilities, and as an evaluation tool after the implementation of the activity, choosing learning media that is appropriate to the material and characteristics of the students, choosing the form of presentation of learning tailored to learning models used for example the use of audio visual media., and simulate the presentation of material with the media and learning steps that have been designed. When the learning simulation takes place also assessments from peers.

The development phase consists of two activities, namely: expert appraisal and developmental testing. Expert appraisal is a technique to validate or assess the feasibility of product design. After the product is repaired, it is then tested again until it gets effective results.

Phase dissemination consists of three activities, namely: validation testing, packaging, diffusion and adoption. At the validation testing stage, products that have been revised at the development stage are then implemented at the actual target. After the product is implemented, the developer needs to see the results of achieving the goals. The goals that have not been reached need to be explored so that the same error does not recur after the product is distributed. Product packaging is done by printing a manual to apply the learning model. After the book is printed, the book is distributed so that it can be absorbed (diffusion) or understood by other people and then adopted for use in other classes.

\section{Result and Discussion}

\subsection{Result}

This research is a research development that aims to produce an effective learning model in learning to write short stories in class XI students. The learning model developed is a synectic model created by Gordon. The model was developed using a 4-D development model. There are 4 stages in the development process, namely defining, designing, developing and distributing.

The first stage is defining or also called development needs analysis. Needs analysis is done by distributing questionnaires and conducting interviews to ensure answers from respondents. The questionnaire was given to two Indonesian language educators and all students who were sampled.

The questionnaire given to educators contained seven statements. The first statement is to recognize the synectic model. Both educators claimed to have known synectic learning models. The statement was strengthened by the results of the interview about how far educators understood the model. Both understand that the synectic model applies the principle of analogy in developing ideas. The second statement is to have used a synectic model in delivering short 
story writing material. Both educators stated that they did but did not always use the model. The use of learning models may change according to learning needs.

The third statement is the presentation of steps in an interesting synectic model and is well used in learning to write short stories. One educator said yes and one educator said no. The fourth statement is the presentation of steps in a systematic learning model and is easy to follow. One educator said yes and one more said no.

The fifth statement is the synectic model to help students write short stories. One educator answered yes and another answered no because there were still many students who had not been able to write short stories. Writing is a scourge for students as revealed by Kurniawan (2014: 82) that the reality that often occurs in learning: (1) every time there is learning to write a story, students must be restless, confused about what to write a story about; (2) if the problem to be told has been found, students are also confused to develop the problem story; (3) that confusion makes students feel writing is a more difficult subject matter than other lessons.

The sixth statement, namely the synectic model, motivates students to think creatively. Both educators agreed with the statement. This is in accordance with Gordon's statement (in Joyce and Weil, 1992: 220) which revealed that the synectic learning model aims to develop student creativity through metaporic activities.

The seventh statement is that it requires the development of a synectic model in learning to write short stories. Both educators stated that they needed the development of a synectic model. Although the existing synectic model is quite successful, educators need a model that is developed by adjusting the existing curriculum and potential.

Furthermore, questionnaires are given to students. The questionnaire contained six statements. The first statement is the learning model that educators have used in short story writing learning that is interesting for students. Second, the learning model that has been used by educators can help understand short story writing learning. Third, the learning model that has been used by educators can motivate learning short story writing material. Fourth, the learning model that has been used by educators increases curiosity in learning to write short stories. Fifth, the learning model that has been used by educators can help creative thinking in the writing process. Sixth, requires the development of learning models in short story writing material.

Almost all students agreed to the statements in the questionnaire given. However, there are still students who do not agree with these statements. This shows that the synectic model applied is not in line with students' expectations and still needs to be developed so that students are able to write short stories easily.

The second stage is design. The researcher prepares the initial design in the form of a conceptual framework which underlies the formation of the steps of the new synectic learning model. Researchers devise instruments to get validation. The instrument that was made for validation was in the form of a questionnaire on the feasibility of learning material and a questionnaire on the feasibility of learning design.

The material eligibility questionnaire consisted of eight indicators totaling 30 questions. The feasibility study design questionnaire consisted of nine indicators which in total consisted of 25 question items. After the questionnaire was prepared, the learning model that had been designed was validated by peers to find out the shortcomings of the product. Products are revised according to peer input.

The third stage is the development phase which aims to produce revised products. At this stage the product is validated by the learning material expert and the learning design is then 
revised according to expert input. Products that have been revised are tested to be expanded to find out their feasibility.

The effectiveness of the product is known by spreading the learning motivation questionnaire to students. The questionnaire contained statements regarding the application of the synectic model that had been developed.

The fourth stage is the final stage in the 4-D process, which is dissemination. After the product is declared eligible, the product is refined in the form of a book entitled "Independent Synectic Model in Short Story Writing Learning".

\subsection{Discussion}

Synectic model development products in learning to write short stories in the form of steps of learning models that have been developed based on the results of needs analysis. The syntactic model that has not yet been developed consists of 6 steps, namely (1) describing the current situation (2) direct analogy (3) personal analogy (4) solid conflict (5) direct analogy (6) re-examining initial tasks. After being developed, the model changed its name to an independent synectic model and consisted of 9 steps, namely (1) idea generation (2) direct analogy 1 (3) personal analogy (4) mapping and discussion (5) filtering of ideas (6) solid conflict (7) ) direct analogy 2 (8) revision (9) writing improvement.

The finished product is then validated by paying attention to aspects of learning material and learning design that are validated by experts. The results of expert validation on the learning material on each indicator that is the relevance of getting a percentage of $96.42 \%$ expressed very good (SB), the accuracy of getting a percentage of $93.75 \%$ was declared very good (SB), the completeness of the presentation getting a percentage of $83.33 \%$ was declared very good ( SB), the systematics of serving received a percentage of $100 \%$ was declared very good (SB), suitability with participant-centered learning got a percentage of $90.62 \%$ declared very good (SB), the method of presentation got a percentage of $93.75 \%$ otherwise very good (SB ), conformity with EBI gets a percentage of $91.66 \%$ expressed very good (SB), and communicativeness gets a percentage of $96.42 \%$ declared very good (SB).

Based on the assessment of the learning material experts on the eight aspects it was found that an average of $91.12 \%$ was in the range of scores of $75 \% \leq X \leq 100 \%$ with excellent criteria (SB). Subsequent scores are converted and an average score of 108 is within the very reasonable criteria. This criterion shows that the learning material on the product is worth testing.

The results of the validation of the learning design on each indicator that is the identification of subjects got a percentage of $100 \%$ expressed very good (SB), the formulation of the indicator got a percentage of $95.83 \%$ declared very good (SB), the learning objectives got a percentage of $93.75 \%$ otherwise very good (SB ), the selection of teaching material gets a percentage of $95.83 \%$ expressed very good (SB), the selection of teaching resources gets a percentage of $100 \%$ declared very good (SB), the selection of instructional media gets a percentage of $95.83 \%$ declared very good (SB), the learning model got a percentage of $93.75 \%$ declared very good (SB), the learning scenario got a percentage of $90.62 \%$ declared very good (SB), and an assessment got a percentage of $90.62 \%$ declared very good (SB).

Based on the assessment of the learning design expert on the nine aspects obtained an average of $95.13 \%$ in the range of scores of $75 \% \leq X \leq 100 \%$ with very good criteria (SB). Subsequent scores are converted and an average score of 82 is a very decent criterion. This criterion shows that the learning design of the product is worth testing. 
Based on expert assessment of the material and design of learning conducted by four experts, it can be concluded that the development of synectic models in learning to write short stories in class XI students of UISU Medan High School is very feasible to be tested in the learning process.

Effectiveness of the synectic models developed in learning to write short stories on the participant students class XI SMA UISU Terrain

The effectiveness of the synectic model in learning to write short stories is seen from the results of the learning motivation questionnaire that was studied by students and the observation sheet of students' activities with established criteria. The effectiveness of the developed synectic model is seen in the results of limited trials and expanded trials and is supported by the results of short story students' ability tests.

The learning motivation questionnaire conducted in a limited trial consisted of twenty items of statements. The overall score is 1570 from the maximum score of 1680 . Based on the acquisition of a learning motivation questionnaire score in a limited trial, the percentage of score acquisition is $93.45 \%$. After being converted to the predetermined value criteria, the score range is at $75 \% \leq X \leq 100 \%$ with very good criteria (SB).

In addition to students 'learning motivation questionnaires, observations of students' activities were carried out to see the effectiveness of the learning models developed. Observations consisted of 10 categories with an overall percentage of $82.37 \%$.

Based on observations of students 'activities and students' learning motivation in limited trials, the data obtained is relevant or mutually supportive. The value obtained indicates that students are motivated in learning to write a short story after using the synectic learning model that has been developed.

After limited trials, the effectiveness of the trials was also seen. The overall score of the learning motivation questionnaire in the trial was expanded by 3805 from the maximum score of 4000 .

Based on the acquisition of learning motivation questionnaire scores in the expanded trial, the percentage of score acquisition was 95.12\%. After being converted to the predetermined value criteria, the score range is at $75 \% \leq X \leq 100 \%$ with very good criteria (SB).

The average percentage of observations of student activity in the expanded trial was $71 \%$. Based on observations of students 'activities and students' learning motivation in expanded trials, the data obtained are relevant or mutually supportive. The value obtained indicates that students are motivated in learning to write short stories after using the synectic learning model that has been developed.

The effectiveness of the learning model is also supported by the results of students' writing tests. Based on the comparison of students before and after using the synectic model in learning to write short stories, the average pretest score is 64.83 and the average posttest score is 80.47. The increase in students' scores on the short story writing test increased by 15.64 . Positive changes indicate that the model developed is effectively used in the learning of short story writing in class XI students of UISU Medan high school. 


\section{Conclusion}

Based on the formulation, objectives, results and discussion in the research development of synectic models in learning to write short stories conducted at Medan UISU High School, it can be concluded that this development is appropriate to be used and disseminated. The learning model that has been developed motivates students to learn short story writing material so that the activeness of students increases. This feasibility is obtained from expert validation of learning materials and learning designs. Besides based on the results of validation, the questionnaire motivation and the results of observations of the activities of students during the learning process took place showing very good results. The assessment results are as follows:

The development process is carried out with a 4-D development research model consisting of defining, designing, developing, and disseminating. Based on an analysis of the needs of educators and students, $100 \%$ of educators and 98.59 students stated that they needed the development of learning models.

The feasibility of the development is seen from the results of the validation of the material expert and the learning design expert on the product development. The results show that the quality of learning materials in the products produced is worth an average percentage of $92.12 \%$ and categorized as very feasible to use. The learning design of the products produced is an average percentage of $95.13 \%$ and categorized as very feasible.

Effectiveness is seen from the results of learning motivation questionnaires and observations of students' activities in limited and expanded trials. Learning motivation questionnaire in limited trials obtained a percentage of $93.45 \%$ with very good criteria and expanded trials obtained a percentage of $95.12 \%$ with very good criteria. The results of observations of the activities of students in limited trials obtained a percentage of 82.37 with very good criteria and trials expanded by $71 \%$ with good criteria.

\section{References}

Akhadiah, Sabarti et al. 1988. Pembinaan Kemampuan Menulis Bahasa Indonesia. Jakarta: Erlangga.

Aminudin. 2009. Pengantar Aprisiasi Karya Sastra. Bandung: Sinar Baru Algensido.

Arikunto, S. 2006. Presedur Penelitian Suatu Pendekatan Praktik . Jakarta: Adhi Mahasatya.

Arikuntoro, Suharsimi. 2006. Prosedur Penelitian Suatu Pendeketan Praktis. Jakarta: Rineka Cipta.

Baribin, Raminah. 1985. Teori dan Apresiasi Prosa Fiksi. Semarang: IKIP Semarang Press.

Djamarah, Syaiful Bahri dan Aswan Zain. 2006. Strategi Belajar Mengajar. Jakarta: PT Rineka Cipta.

Endah, Tri Priyatni. 2014. Desain Pembelajaran Bahasa Indonesia Dalam Kurikulum 2013. Jakarta: Bumi Aksara.

Endraswara, S. 2006. Metodologi Penelitian Dalam Sastra. Yogyakarta: Pustaka Widyatama.

Eristi, B., \& Mustofa Polat. 2017. The Effectiviness of Synectics Instructional Model on Foreign Languange Vocabullary Teaching. International Journal of Languange Education and Teaching. 5(2) : 59-76.

Gani. Rizanur. 1988. Pengajaran Sastra Indonesia Respons dan Analisis. Jakarta: Depdikbud. Hamalik, Oemar. 1994. Media Pendidikan. Bandung: Citra Aditya Bhakti.

Harianto. GP. 1995. Mengenal Karakteristik Sajak-Cerita Pendek. Bandung: Agiamedia. 
Hariwijaya. M. 2007. Jurus Maut Menulis dan Menerbitkan Buku. Yogyakarta: Eimatera Publishing.

Hastuti, P.H.S. 1996. Strategi Belajara Mengajar Bahasa Indonesia. Jakarta: Depdikbud.

Hosna, Rofiatul. 2013. Pengembangan Model Pembelajaran Sinektik di Madrasah Ibtidaiyah. Jurnal Bahasa dan Sastra Indonesia. 28 (2) : 237-252.

Huda, Miftahul. 2014. Model-model Pengajaran dan Pembelajaran. Yogyakarta: Pustaka Pelajar.

Jabrohim, Chairul Anwar dan Suminto A. Sayuti. 2003. Cara Menulis Kreatif. Jakarta: Pustaka Pelajar.

Jabrohim. 1994. Pengajaran Sastra. Yogyakarta: Pustaka Pelajar.

Joharis. 2017. The Effect of Leadership, Organizational Culture, Work Motivation and Job Satisfaction on Teacher Organizational Commitment at Senior High School in Medan. The Turkish Online Journal of Design, Art and Communication TOJDAC. 116 : 14151425.

Joharis and Haidir. 2019. Administrasi dan Perencanaan Pengembangan Sumber Daya Manusia. Jakarta : Prenadamedia.

Joyce, Bruce, Marsha Weil, and Emily Calhoun. 2011. Models of Teaching. Yogyakarta: Pustaka Pelajar.

Karwati, Uus. 2012. Aplikasi Model Pembelajaran Sinektik (Synectic Model.Jurnal Seni \& Budaya Panggung. 22(2): 147-159.

Komaidi, Didik. 2008. Aku Bisa Menulis Panduan Praktis Menulis Kreatif Lengkap. Yogyakarta: Sabda Media.

Kosasih, E. 2009. Mantap Bersastra Indonesia. Bandung: Yrama Widya.

Kurnia, Sayuti, et al. 1996. Teori Sastra. Jakarta: Depdikbud.

Kurniawan, Heru and Sutardi. 2011. Penulisan Sastra Kreatif. Yogyakarta: Graha Ilmu.

Kusmayadi, Ismail. 2010. Lebih Dekat dengan Cerpen. Jakarta: Trias Yoga Kreasindo.

Lisnawati, Iis. 2014. Pembelajaran Bahasa Indonesia Berbasis Strategi Belajar Bahasa sebagai Pendukung Implementasi Kurikulum 2013.Jurnal Bahasa \& Sastra. 14(1) : 43-57.

Listini and Saraswati. 2017. Meningkatkan Kemampuan Menulis Cerpen Melalui Model Pembelajaran Sinektik Siswa Kelas VII SMP Sandika Sukajadi. Jurnal Bindo Sastra. 1 (1) : 24-27.

Munarto. 2016. Pengembangan Model Sinektik Terpimpin Berwawasan Lingkungan Menulis Puisi dalam Pembentukan Moral Siswa. Jurnal Pendidikan Bahasa dan Sastra Indonesia. $5(1): 1-5$.

Nadeak, Wilson. 1989. Bagaimana Menulis Cerita Pendek. Bandung: Yayasan Kalam Hidup.

Nurgiyantoro, Burhan. 2010. Teori Pengkajian Fiksi. Yogyakarta: Universitas Gajah Mada.

Nurul, Hayati. 2002. Model Pembelajaran . Jakarta: Erlangga.

Nursito. 2000. Ikhtisar Kesusastraan Indonesia. Yogyakarta : Adicita Karya Nusa.

Nurudin. 2007. Dasar-dasar Penulisan. Solo: UMM Press.

Nuryatin, Agus. 2010. Mengabadikan Pengalaman dalam Cerpen. Rembang: Yayasan Adhigama.

Poteet. 2004. Writing as a Skill. London : Longman.

Priggawidagda, Suwarna. 2002. Strategi Penguasaan Berbahasa. Yogyakarta: Adicita Karya Nusa.

Priyanti, Endah Tri. 2014. Desain Pembelajaran Bahasa Indonesia dalam Kurikulum 2013. Jakarta: Bumi Aksara.

Rahmanto. B. 1988. Metode Pengajaran Sastra. Yogyakarta : Kanisius. 
Ramadhani, S., Khairil Ansari, Wisman Hadi. 2017. The Effect os Synectics Learning Model and Vocabulary Mastering to Student Writing Poetry Skill in Grade V SDN 066041 Medan Academic Year 2016/2017. Journal od Research \& Method in Education (IOSRJRME). 7(5) : 80-88.

Rohani, Ahmad. 1997. Media Instruksional Edukatif. Jakarta : Rineka Cipta.

Sayuti, Suminto A. 2000. Berkenalan dengan Prosa Fiksi. Yogyakarta: Gama Media.

Semi, M Atar. 1988. Anatomi Sastra. Padang: Angkasa Raya Padang.

Silbermen, Mel. 2005. Active Learning. Yogyakarta:Pustaka Insan Madani.

Soeparno.1988. Media Pengajaran Bahasa. Yogyakarta: Intan Pariwara.

Staton, Robert.2007. Teori Fiksi. Yogyakarta : Pustaka Pelajar.

Subyantoro. 2009. Penelitian Tindakan Kelas. Semarang : Widya Karya.

Sudjana. Nana and Ahmad Rivai. 2009. Media Pengajaran. Bandung: Sinar Baru Algensindo.

Sugiyono. (2008). Metodologi Penelitian Pendidikan Kualitatif, Kuantitatif, dan R\&D. Bandung: Alfabeta.

Suharianto. 2005. Dasar-Dasar Teori Sastra. Semarang: Rumah Indonesia.

Sumardjo. Jakob and Saini. K.M. 1994. Apresiasi Kesusastraan. Jakarta: Gramedia Pustaka Utama.

Sumardjo, Jacob. 2007. Catatan Kecil Tentang Menulis Cerpen. Yogyakarta: Pustaka Pelajar.

Supriyadi. 2014. Peningkatan Kemampuan Menulis Puisi dengan Model Sinektik. Jurnal Pemikiran dan Pengembangan SD. 1(3) : 201-211.

Sutikno. 2016. Pengembangan Model Sinektik pada Pembelajaran Menulis Puisi Berkonteks Multikultural dalam Pembentukan Karakter Siswa SMA. Journal Indonesian Languange Education and Literature. 1(2) : 101-114.

Trianto. 2007. Model Pembelajaran Terpadu dalam Teori dan Praktek. Jakarta: Prestasi Pustaka.

Wijaya, S. 2008. Model-model Pembelajaran Inovatif Berotientasi Konstruktivitik. Jakarta: PT Gramedia.

Winaputra, Udin. S. (2005). Model-model Pembeljaran Inovativ. Jakarta: Universitas Terbuka. Wiyanto. Asul. 2005. Kesusastraan Sekolah. Jakarta: Grasindo. 